\title{
Regulation of the pacemaker activities in cultured interstitial cells of Cajal by Citrus unshiu peel extracts
}

\author{
JI HWAN SHIM ${ }^{1,2}$, SOO JIN LEE ${ }^{1,2}$, HUIJIN GIM ${ }^{1,2}$, HYUN JUNG KIM ${ }^{1,2}$, TAEWON HAN ${ }^{3}$, \\ JAE GOO KIM ${ }^{3}$, EUN YEONG LIM ${ }^{3,4}$, YUN TAI KIM ${ }^{3,4}$ and BYUNG JOO KIM ${ }^{1,2}$ \\ ${ }^{1}$ Division of Longevity and Biofunctional Medicine and ${ }^{2}$ Healthy Aging Korean Medical Research Center, \\ School of Korean Medicine, Pusan National University, Yangsan, Gyeongsangnamdo 50612; \\ ${ }^{3}$ Research Group of Innovative Special Food, Korea Food Research Institute, Seongnam, Gyeonggi 13539; \\ ${ }^{4}$ Department of Food Biotechnology, Korea University of Science \& Technology, Daejeon 34113, Republic of Korea
}

Received October 5, 2015; Accepted August 9, 2016

DOI: $10.3892 / \mathrm{mmr} .2016 .5689$

\begin{abstract}
The Citrus unshiu peel has been widely used for the treatment of gastrointestinal(GI) disordersinEasterntraditional medicine. The present study aimed to investigate the effects of Citrus unshiu peel extract (CPE) on the pacemaker activity of the GI tract in cultured interstitial cells of Cajal (ICCs) derived from the mouse small intestine. The whole-cell patch-clamp configuration was used to record pacemaker potentials. In current clamp mode, exposure to CPE caused membrane pacemaker depolarization in a concentration-dependent manner. In the presence of the muscarinic $\mathrm{M}_{2}$ receptor antagonist, methoctramine, CPE induced membrane pacemaker depolarization, whereas treatment with the muscarinic $\mathrm{M}_{3}$ receptor antagonist, 1,1-dimethyl-4-diphenylacetoxypiperidinium iodide, inhibited CPE-induced responses. When the pipette solution contained guanosine 5'-( $\beta$-thio) diphosphate trilithium salt (1 mM), CPE marginally induced membrane pacemaker depolarization. In addition, CPE-induced membrane pacemaker depolarization was inhibited following exposure to the active phospholipase C (PLC) inhibitor U-73122, but not the inactive PLC inhibitor U-73343. In the presence of a p42/p44 mitogen-activated protein kinase (MAPK) inhibitor (PD98059), a p38 MAPK inhibitor (SB203580) or a c-jun NH2-terminal kinase (JNK) II inhibitor, CPE failed to induce membrane pacemaker depolarization. These results suggest that CPE may affect GI motility through modulating ICC pacemaker activity by activating the muscarinic $\mathrm{M}_{3}$ receptor and inducing the G-protein dependent PLC and MAPK signaling pathways.
\end{abstract}

Correspondence to: Professor Byung Joo Kim, Division of Longevity and Biofunctional Medicine, School of Korean Medicine, Pusan National University, 49 Busandaehakro, Mulgeum-eup, Yangsan, Gyeongsangnamdo 50612, Republic of Korea E-mail: vision@pusan.ac.kr

Key words: interstitial cells of Cajal, whole-cell patch-clamp configuration, pacemaker potential, Citrus unshiu peel extract, gastrointestinal tract

\section{Introduction}

Traditional plant-based medicines have served an important role in health care, and numerous drugs are known to originate from these medicines (1). Citrus unshiu (C. unshiu) Marcov, which belongs to the Rutaceae family is a seedless and easy-to-peel Korean citrus fruit, and constitutes 30\% of the total volume of fruit produced in Korea (2). Its dried peel has been used to improve bronchial and asthmatic conditions, and blood circulation in Korea, China, and Japan for thousands of years $(3,4)$.

The $C$. unshiu peel (also known as Jin-pee) is the primary waste product of citrus fruits and has been used as a source of molasses, pectin, cold-pressed oils and limonene (5). The peel has been studied extensively, as it contains numerous biologically active compounds, such as natural antioxidants (phenolic acids and flavonoids) (6,7). In addition, the C. unshiu peel is reported to possess anti-allergy $(8,9)$, antibacterial, anti-fungal $(10,11)$, anticancer $(12)$, antidiabetic $(13,14)$, anti-inflammatory (15,16), antioxidant (17-19), antiviral (20) and lipid-lowering activities $(2,4)$. C. unshiu peel has been used in Korea to treat a variety of digestive disorders, including tympanites, nausea, vomiting and dyspepsia $(16,21)$. Despite reports that the peel functions as a prokinetic agent to prevent or alleviate gastrointestinal (GI) motility dysfunctions (22), little is known about its effects on GI motility or its mechanisms of action.

Interstitial cells of Cajal (ICCs) are the pacemaker cells of the GI muscles that generate rhythmic oscillations in membrane potentials (termed 'slow waves') $(23,24)$, and mediate or transduce inputs from the enteric nervous system (25). Research into the biology of ICCs has provided exciting and novel opportunities to understand the etiology of GI diseases (26). Therefore, the aim of the present study was to investigate the effect of $C$. unshiu peel extracts (CPE) on the pacemaker potentials of cultured ICCs from the murine small intestine.

\section{Materials and methods}

Preparation of samples and high-performance liquid chromatography (HPLC) analysis. The dried peel of C. unshiu was 
purchased from Kapdang Co. (Seoul, Korea). The sample was identified by Dr Yun Tai Kim (Korea Food Research Institute, Seongnam, Korea) according to the 'Illustrated Guide to Clinical Medical Herbs' (27) and a voucher specimen (reference no. NP-1505) was deposited with the Research Group of Innovative Special Food (Korea Food Research Institute). C. unshiu dried peel (600 g) was incubated with $70 \%$ ethanol $(6,000 \mathrm{ml})$ for $2 \mathrm{~h}$ at $20^{\circ} \mathrm{C}$. This process was repeated with fresh $70 \%$ ethanol, and the extract solution was combined and filtered through a $0.45-\mu \mathrm{m}$ membrane filter (EMD Millipore, Billerica, MA, USA). The solvents were removed by rotary evaporation and the remaining extracts were freeze-dried, which yielded $21.1 \%$ of the dried peel weight (w/w).

The freeze-dried extract powder $(100 \mathrm{mg})$ was dissolved in $5 \mathrm{ml}$ methanol/dimethyl sulfoxide (DMSO; 1:1, v/v), before it was filtered through a $0.45-\mu \mathrm{m}$ regenerated cellulose-membrane filter (Sartorius AG, Goettingen, Germany), and diluted in methanol/DMSO $(1: 1, \mathrm{v} / \mathrm{v})$ to a final concentration of $10 \mathrm{mg} / \mathrm{ml}$ prior to injection of $10 \mu \mathrm{l}$ of the solution into the HPLC. Analytical HPLC was performed using a Jasco HPLC system (Jasco, Inc., Tokyo, Japan), which comprised a PU-980 pump, an AS-950-10 autosampler and an MD-2010 Plus multi-wavelength detector.

The chromatographic separation was conducted at $30^{\circ} \mathrm{C}$ using a Symmetry ${ }^{\circledR}$ C18 column $(4.6 \times 250 \mathrm{~mm}$, particle size $5 \mu \mathrm{m}$; Waters Corporation, Milford, MA, USA) with gradient elution using a mobile phase composed of $40 \%$ methanol (mobile phase A) and 100\% methanol (mobile phase B). Alterations in the mobile phase was achieved using a linear gradient system from $100 \%$ mobile phase A to $100 \%$ mobile phase B over $30 \mathrm{~min}$ and with a $0.5 \mathrm{ml} / \mathrm{min}$ flow rate, before the samples were detected at $284 \mathrm{~nm}$. Quantitative analysis was performed in triplicate. The regression equation and correlation coefficient $\left(r^{2}\right)$ of each standard curve were automatically calculated by the Jasco HPLC system. The regression equations for narirutin and hesperidin were $y=35,103.0278 x-55,481.6311$ $\left(r^{2}, 0.99994\right)$ and $y=39,824.0428 x-72,092.8906\left(r^{2}, 0.99973\right)$, respectively, indicating that a high linear correlation was achieved for all standard curves. The concentration of narirutin and hesperidin were determined to be $21.72 \pm 0.716$ and $8.51 \pm 0.296 \mathrm{mg} / \mathrm{g}$, respectively using the peak area in the chromatogram and the regression equation (Fig. 1).

Ethical approval. Animal care and experiments were conducted in accordance with the guidelines issued by the ethics committee of Pusan National University (Busan, Korea; approval no. PNU-2014-0725) and the Guide for the Care and Use of Laboratory Animals published by the US National Institute of Health (NIH Publication No. 85-23, revised 2011).

Preparation of cells and culture conditions. A total of 82 male (52\%) and female (48\%) BALB/c mice (age, 3-7 days; weight, 1.9-2.2 g; Samtako Bio Korea Inc., Osan-si, Korea) were anesthetized with ether and euthanized by cervical dislocation. They were maintained under controlled conditions (temperature, $21 \pm 3^{\circ} \mathrm{C}$; humidity $50 \pm 6 \%$; $12 \mathrm{~h} \mathrm{light/dark}$ cycles) and were allowed free access to food and water. Mice were fed a diet comprised of crude protein $(\geq 18 \%)$, crude fat $(\geq 5 \%)$, crude fiber $(\leq 4.5 \%)$, crude ash $(\leq 8 \%)$, calcium $(\geq 0.7 \%)$ and phosphorus $(\leq 1.2 \%)$ (Samtako Bio Korea Inc.). The small intestines from $1 \mathrm{~cm}$ below the pyloric ring to the cecum were removed, opened along the mesenteric border, and the luminal contents were removed by washing with a Krebs-Ringer bicarbonate solution. Tissues were pinned to the base of a Sylgard dish and the mucosae were removed by sharp dissection. Small tissue strips of intestinal muscle, consisting of circular and longitudinal muscles, were equilibrated in a $\mathrm{Ca}^{2+}$-free Hank's Balanced Salt Solution (containing $5.36 \mathrm{mmol} / \mathrm{l} \mathrm{KCl}$, $125 \mathrm{mmol} / 1 \mathrm{NaCl}, 0.34 \mathrm{mmol} / \mathrm{l} \mathrm{NaOH}, 0.44 \mathrm{mmol} / 1 \mathrm{Na}_{2} \mathrm{HCO}_{3}$, $10 \mathrm{mmol} / 1$ glucose, $2.9 \mathrm{mmol} / 1$ sucrose and $11 \mathrm{mmol} / 1$ HEPES) for $30 \mathrm{~min}$. Cells were then dispersed using an enzyme solution containing $1.3 \mathrm{mg} / \mathrm{ml}$ collagenase (Worthington Biochemical Corporation, Lakewood, NJ, USA), $2 \mathrm{mg} / \mathrm{ml}$ bovine serum albumin (Sigma-Aldrich; Merck Millipore, Darmstadt, Germany), $2 \mathrm{mg} / \mathrm{ml}$ trypsin inhibitor (Sigma-Aldrich; Merck Millipore) and $0.27 \mathrm{mg} / \mathrm{ml}$ adenosine triphosphate (ATP; Sigma-Aldrich; Merck Millipore). Cells were subsequently plated onto Falcon sterile glass coverslips coated with murine collagen $(2.5 \mu \mathrm{g} / \mathrm{ml}$; BD Biosciences, Franklin Lakes, NJ, USA) in a $35-\mathrm{mm}$ culture dish, and maintained in smooth muscle growth medium (Clonetics Corporation, San Diego, CA, USA) supplemented with 2\% Penicillin-Streptomycin solution (Gibco; Thermo Fisher Scientific, Waltham, MA, USA) and $5 \mathrm{ng} / \mathrm{ml}$ murine stem cell factor (Sigma-Aldrich; Merck Millipore) at $37^{\circ} \mathrm{C}$ in an $\mathrm{O}_{2}(95 \%) / \mathrm{CO}_{2}(5 \%)$ incubator. ICCs were identified immunocytochemically by incubating cells with a phycoerythrin-conjugated rat anti-mouse monoclonal anti-c-Kit antibody (cat. no. 12-1172; dilution, 1:50; eBioscience, Inc., San Diego, CA, USA) for $20 \mathrm{~min}$ as described previously (28). ICCs were morphologically distinct from other cell types in culture, and it was therefore possible to identify these cells by phase contrast microscopy after they had been stained with the anti-c-Kit antibody.

Patch-clamp experiments. The whole-cell patch-clamp configuration was used to record membrane potentials (in current clamp mode) in cultured ICCs. An Axopatch 1D (Molecular Devices, LLC, Sunnyvale, CA, USA) was used to amplify membrane currents and potentials. The command pulse was applied using pCLAMP software (version 6.1; Molecular Devices, LLC). Data were obtained by filtering at $5 \mathrm{kHz}$ and were displayed on an oscilloscope, a computer monitor, and detected using a Gould 2200 Series Analog Recorder (Gould Instrument Systems, Inc., Valley View, OH, USA). Results were analyzed using pCLAMP and Origin software (version 6.0; MicroCal, Northampton, MA, USA). All experiments were performed at $30-32^{\circ} \mathrm{C}$.

Solutions and drugs. The physiological salt solution used to bathe cells $\left(\mathrm{Na}^{+}\right.$-containing Tyrode's Solution) consisted of $5 \mathrm{mmol} / 1 \mathrm{KCl}, 135 \mathrm{mmol} / 1 \mathrm{NaCl}, 2 \mathrm{mmol} / 1 \mathrm{CaCl}_{2}, 10 \mathrm{mmol} / 1$ glucose, $1.2 \mathrm{mmol} / 1 \mathrm{MgCl}_{2}$ and $10 \mathrm{mmol} / 1 \mathrm{HEPES}$, adjusted to $\mathrm{pH} 7.4$ with $\mathrm{NaOH}$. CPE (1-10 $\mathrm{mg} / \mathrm{ml})$ was added to ICC bath solutions for $2 \mathrm{~min}$. The pipette solution consisted of $140 \mathrm{mmol} / 1 \mathrm{KCl}, 5 \mathrm{mmol} / 1 \mathrm{MgCl}_{2}, 2.7 \mathrm{mmol} / 1 \mathrm{~K}_{2} \mathrm{ATP}$, $0.1 \mathrm{mmol} / \mathrm{l} \mathrm{NaGTP}, 2.5 \mathrm{mmol} / \mathrm{l}$ creatine phosphate disodium, $5 \mathrm{mmol} / 1 \mathrm{HEPES}$ and $0.1 \mathrm{mmol} / 1$ EGTA adjusted to $\mathrm{pH} 7.2$ with KOH. All drugs including, methoctramine, diphenylacetoxypiperidinium iodide (4-DAMP), guanosine 5'-( $\beta$-thio) diphosphate trilithium salt (GDP- $\beta-S)$, U-73312, U-73343, 
PD98059, SB203580 and the JNK II inhibitor SP600125, were obtained from Sigma-Aldrich (Merck Millipore). Drugs were dissolved in distilled water and added to the physiological salt solution at the desired concentrations immediately prior to use. The addition of these drugs to the solution for $5 \mathrm{~min}$ did not alter the pH. 4-DAMP was dissolved in DMSO to produce a $50 \mathrm{mmol} / \mathrm{l}$ stock solution, which was subsequently added to the bathing solution at a final concentration of $10 \mu \mathrm{M}$ on the day of the experiment for $5 \mathrm{~min}$. The final concentration of DMSO in the culture solution was $<0.1 \%$ and preliminary experiments confirmed that this concentration of DMSO did not affect results. In addition, $25 \mu 1$ methoctramine was dissolved in distilled water to produce a $50 \mathrm{mmol} / 1$ stock solution, which was added to the culture solution at a final concentration of $10 \mu \mathrm{M}$ on the day of the experiment for $5 \mathrm{~min}$. GDP- $\beta$-S was dissolved in DMSO to produce a $1 \mathrm{~mol} / \mathrm{l}$ stock solution, which was added to the pipette solution at a final concentration of $1 \mathrm{mM}$ on the day of the experiment. Both U-73312 and U-73343 were dissolved in DMSO to produce a $5 \mathrm{mmol} / 1$ stock solution, which was added to the culture solution at a final concentration of $5 \mu \mathrm{M}$ on the day of the experiment for $5 \mathrm{~min}$. PD98059, SB203580 and the JNK II inhibitor were dissolved in DMSO to produce $10 \mathrm{mmol} / \mathrm{l}$ stock solutions, which were added to the culture solution at a final concentration of $10 \mu \mathrm{M}$ on the day of the experiment for $5 \mathrm{~min}$.

Statistical analysis. Results are expressed as the mean \pm standard error. The Student's $t$-test and one-way analysis of variance with Bonferroni's post-hoc tests were used to test for significance among groups. $\mathrm{P}<0.05$ was considered to indicate a statistically significant difference. The $n$ values refer to the number of cells used in patch-clamp experiments.

\section{Results}

Effect of CPE on pacemaker potentials in cultured ICCs. The initial aim of the current study was to investigate the effects of CPE on ICC pacemaker potentials. Recordings from cultured ICCs under current clamp mode ( $\mathrm{I}=0)$ demonstrated the occurrence of spontaneous pacemaker potentials, with a resting membrane potential of $-58.2 \pm 1.2 \mathrm{mV}$ and an amplitude of $25.3 \pm 1.7 \mathrm{mV}$. In the presence of CPE $(1-10 \mathrm{mg} / \mathrm{ml})$, membrane potentials were significantly depolarized compared with the control group to $6.8 \pm 1.0 \mathrm{mV}$ at $1 \mathrm{mg} / \mathrm{ml}(\mathrm{P}=0.0012)$, $24.8 \pm 1.3 \mathrm{mV}$ at $5 \mathrm{mg} / \mathrm{ml}(\mathrm{P}<0.0001)$ and $28.8 \pm 0.9 \mathrm{mV}$ at $10 \mathrm{mg} / \mathrm{ml}(\mathrm{P}<0.0001) \mathrm{CPE}$, with corresponding significantly reduced amplitudes of $20.2 \pm 1.5 \mathrm{mV}(\mathrm{P}=0.012), 2.3 \pm 0.5 \mathrm{mV}$ $(\mathrm{P}<0.0001)$ and $2.2 \pm 0.6 \mathrm{mV}(\mathrm{P}<0.0001)$, respectively (Fig. 2A-D). A summary of values, together with a bar graph demonstrating the effects of $\mathrm{CPE}$ on pacemaker potentials are provided in Fig. 2E and $\mathrm{F}(\mathrm{n}=7)$.

Identification of CPE-target receptor subtypes in cultured ICCs. Muscarinic receptors are known to mediate membrane depolarization and excitatory junction potentials in the GI tract $(29,30)$. In addition, it has been reported that isolated ICCs express $M_{2}$ and $M_{3}$ muscarinic receptor subtypes in the GI tract (31). Therefore, in order to determine whether $\mathrm{CPE}$-induced membrane depolarization involves muscarinic receptors, the effect of CPE on $\mathrm{M}_{2}$ and $\mathrm{M}_{3}$ muscarinic receptors

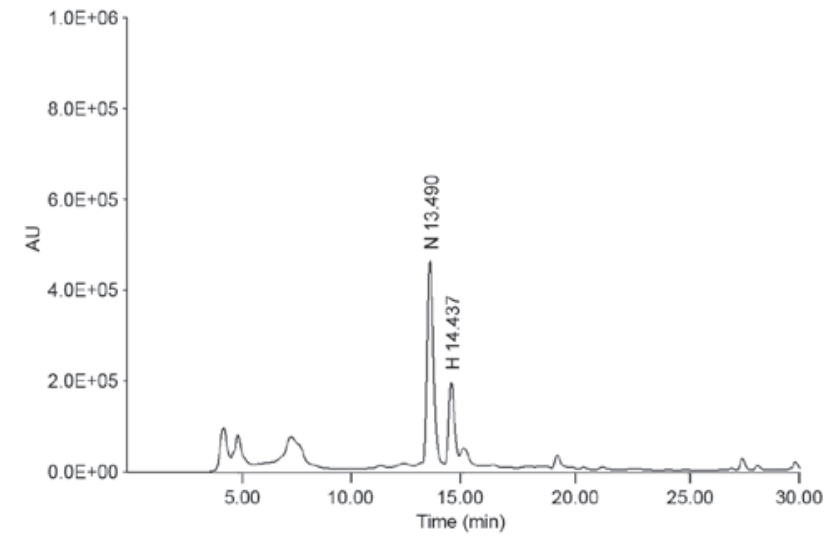

Figure 1. Chromatogram demonstrating the composition of Citrus unshiu peel extracts as determined by high-performance liquid chromatography. $\mathrm{N}$, narirutin; $\mathrm{H}$, hesperidin; $\mathrm{AU}$, absorption unit.

was investigated. ICCs were pretreated with muscarinic receptor antagonists prior to treatment with CPE. To achieve this, ICCs were first exposed to the muscarinic $\mathrm{M}_{2}$ receptor antagonist, methoctramine, and the muscarinic $\mathrm{M}_{3}$ receptor antagonist, 4-DAMP, at a concentration of $10 \mu \mathrm{M}$ for $5 \mathrm{~min}$, before $5 \mathrm{mg} / \mathrm{ml} \mathrm{CPE}$ was added. Treatment with methoctramine or 4-DAMP alone did not affect pacemaker potentials (data not shown), and pretreatment with methoctramine did not significantly inhibit the effect of CPE on the pacemaker potential compared with CPE treatment alone (Fig. 3A). Membrane depolarization in the presence of methoctramine by CPE was $23.7 \pm 1.1 \mathrm{mV}(\mathrm{n}=6)$, however, following the pretreatment of ICCs with 4-DAMP, membrane depolarization was inhibited compared with CPE treatment alone $(\mathrm{P}<0.0001$; Fig. 3B and C). The membrane depolarization signal produced in the presence of 4-DAMP was $0.6 \pm 0.6 \mathrm{mV}$ ( $\mathrm{n}=6$; Fig. $3 \mathrm{C}$ ). These results suggest that CPE may affect ICC membrane potential through the $\mathrm{M}_{3}$ receptor.

Involvement of G-proteins in CPE-induced depolarization of pacemaker potentials in cultured ICCs. The effect of $\mathrm{CPE}$-induced pacemaker potential depolarization in ICCs following treatment with GDP- $\beta$-S, a non-hydrolysable guanosine 5 '-diphosphate analogue that permanently inactivates G-protein binding proteins $(32,33)$, was examined in order to determine the role of $\mathrm{G}$ proteins in mediating this effect. As demonstrated in Fig. 2C, CPE ( $5 \mathrm{mg} / \mathrm{ml})$ induced ICC membrane depolarization. However, upon exposure to $1 \mathrm{mM}$ GDP- $\beta-S, C P E$ membrane depolarization was only partially induced compared with CPE alone (Fig. 4A). As a result, the membrane depolarization induced by $\mathrm{CPE}$ was significantly reduced in the presence of GDP- $\beta-\mathrm{S}(\mathrm{P}=0.0009 ; \mathrm{n}=6$; Fig. 4B). These results suggest that $G$ proteins may be involved in mediating CPE-induced pacemaker depolarization in ICCs.

Effect of phospholipase C (PLC) inhibition on CPE-induced pacemaker potential depolarization. A previous study demonstrated that membrane depolarization in ICCs may be associated with intracellular $\mathrm{Ca}^{2+}$ mobilization (28). Therefore, the current study aimed to determine whether the CPE-induced effects on the pacemaker potential of ICCs 
A

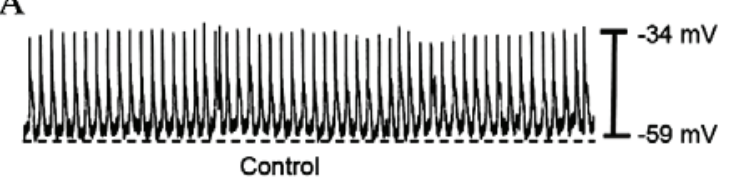

C

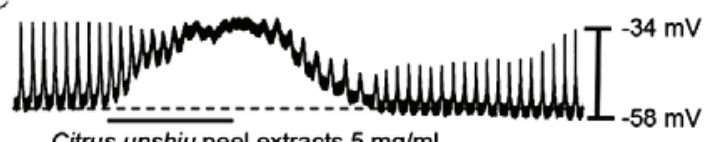

Citrus unshiu peel extracts $5 \mathrm{mg} / \mathrm{ml}$

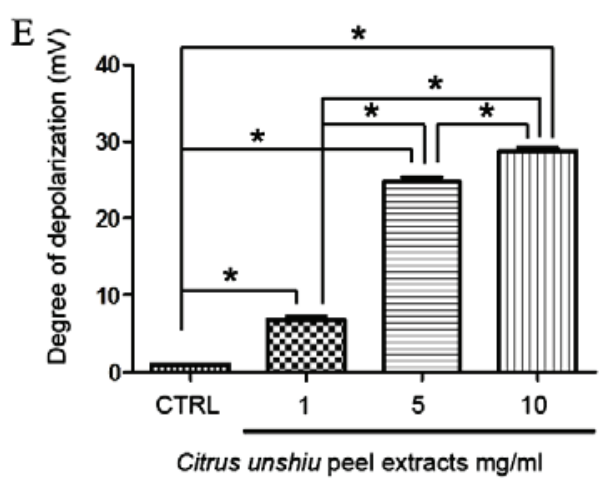

B

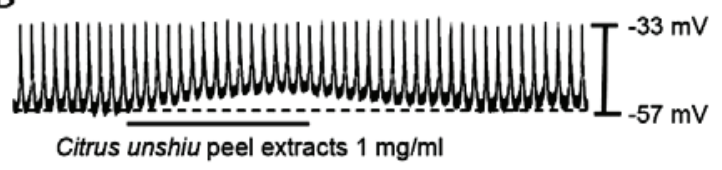

D
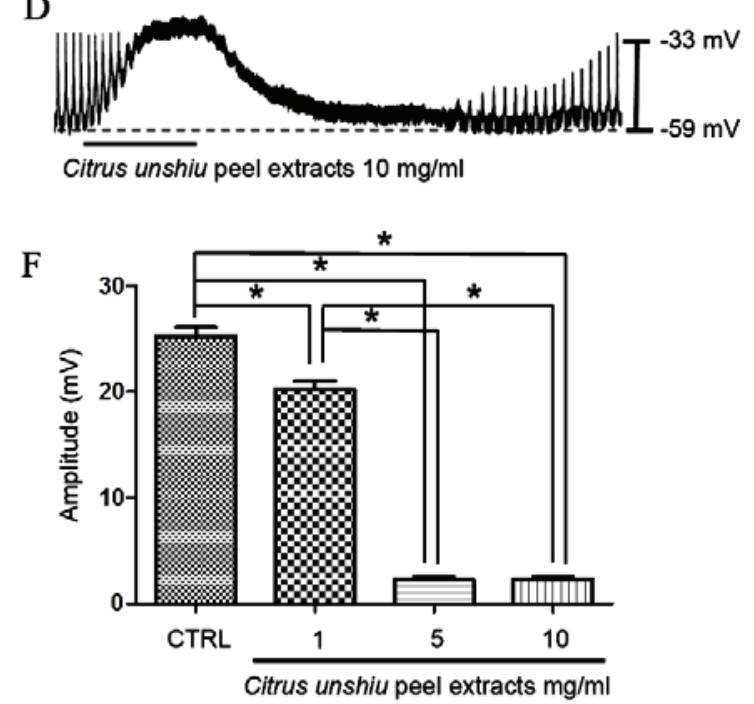

Figure 2. Effects of CPE on pacemaker potentials in cultured ICCs from the murine small intestine. The pacemaker potentials in current clamp mode (I=0) of (A) untreated control ICCs, and those treated with (B) $1 \mathrm{mg} / \mathrm{ml}$ (C) $5 \mathrm{mg} / \mathrm{ml}$ and (D) $10 \mathrm{mg} / \mathrm{ml} \mathrm{CPE}$. Responses to CPE are summarized as (E) the degree of depolarization and $(\mathrm{F})$ the amplitude of the pacemaker potential. Data are presented as the mean \pm standard error of 7 experiments. ${ }^{*}<0.05$ vs. indicated treatment groups. CPE, Citrus unshiu peel extracts, ICCs, interstitial cells of Cajal; CTRL, control.
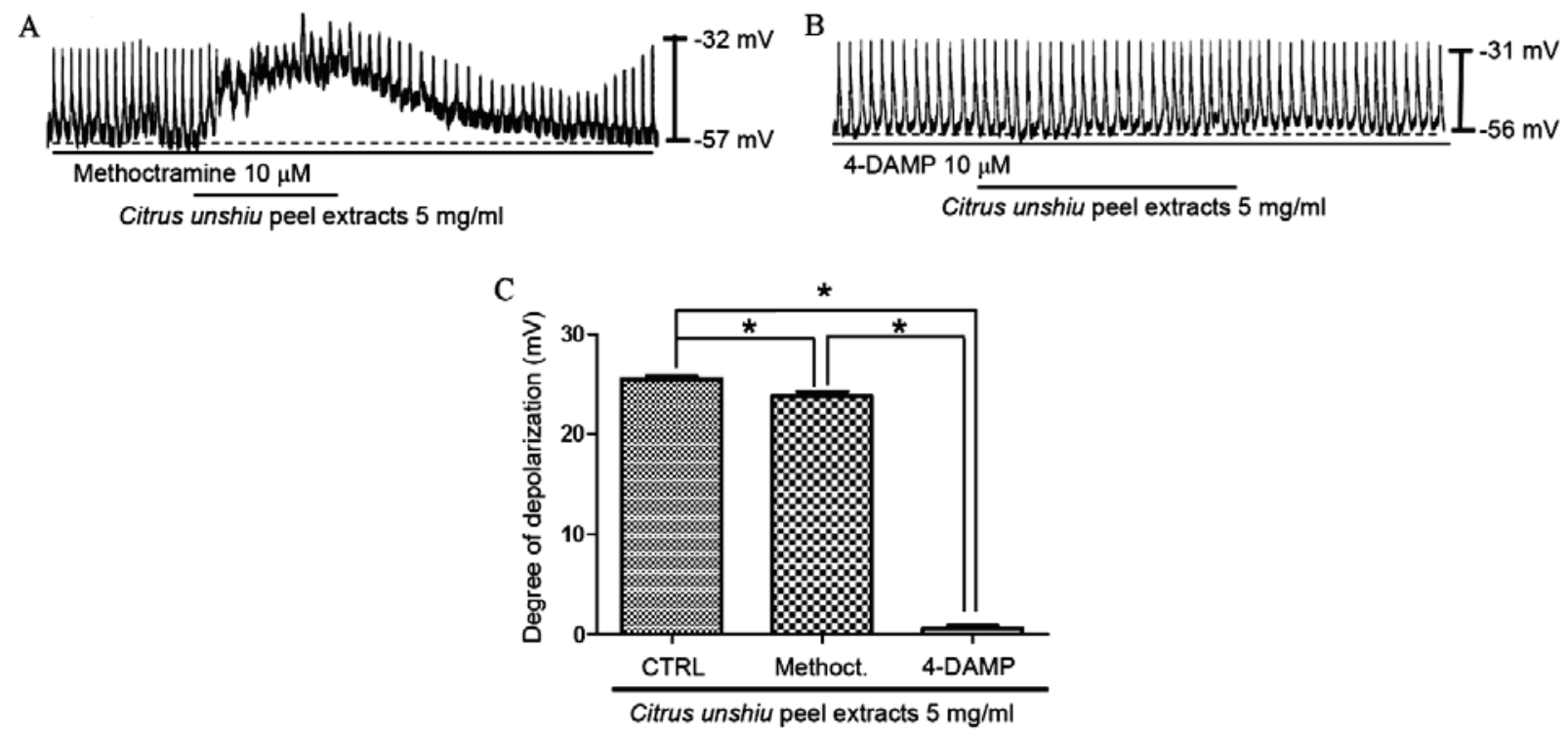

Figure 3. Effect of muscarinic receptor subtype antagonists on CPE-induced pacemaker potential depolarization in cultured ICCs. The pacemaker potentials of ICCs exposed to (A) $10 \mu \mathrm{M}$ methoctramine (a muscarinic $\mathrm{M}_{2}$ receptor antagonist) or (B) $10 \mu \mathrm{M}$ 4-DAMP (a muscarinic $\mathrm{M}_{3}$ receptor antagonist) prior to treatment with $5 \mathrm{mg} / \mathrm{ml} \mathrm{CPE}$. Pacemaker potentials were depolarized in the presence of methoctramine, but were unchanged following exposure to 4-DAMP. (C) Summary of the degree of membrane depolarization following exposure to CPE in the presence of methoctramine and 4-DAMP receptor antagonists. Results are presented as the mean \pm standard error of 6 experiments. ${ }^{*}<<0.05$ vs. indicated treatment groups. CPE, Citrus unshiu peel extracts, ICCs, interstitial cells of Cajal; 4-DAMP, 1,1-dimethyl-4-diphenylacetoxypiperidinium iodide; CTRL, control.

require PLC. To investigate this, CPE $(5 \mathrm{mg} / \mathrm{ml})$-induced membrane depolarization in the absence and presence of the active PLC inhibitor U-73122 $(5 \mu \mathrm{M})$ was examined (34). As demonstrated in Fig. 5A, CPE-induced pacemaker membrane depolarization was eliminated upon exposure of cells to U-73122. Under these conditions, CPE induced minor membrane depolarization ( $\mathrm{n}=5$; Fig. $5 \mathrm{~A}$ ). In the presence of U-73122, the membrane depolarization produced by CPE was 
A [GDP- $\beta-S 1 \mathrm{mM}$ ]

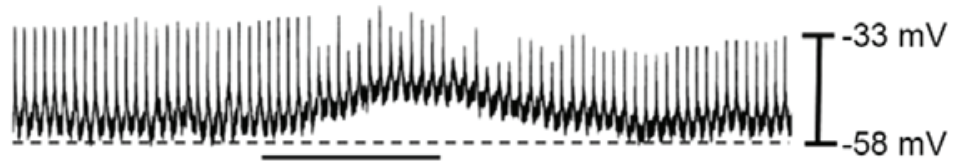

Citrus unshiu peel extracts $5 \mathrm{mg} / \mathrm{ml}$

B

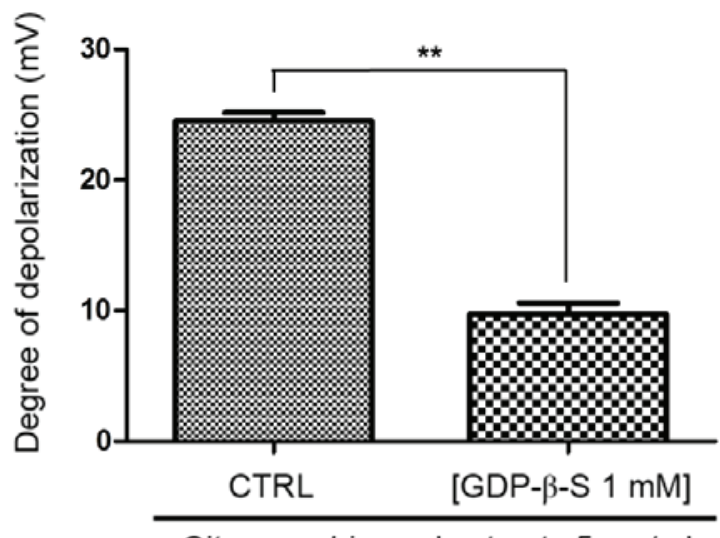

Citrus unshiu peel extracts $5 \mathrm{mg} / \mathrm{ml}$

Figure 4. Effect of GDP- $\beta$-S on CPE-induced pacemaker potential depolarization in cultured ICCs. (A) Pacemaker potentials of ICCs exposed to CPE $(5 \mathrm{mg} / \mathrm{ml})$ in the presence of GDP- $\beta-\mathrm{S}(1 \mathrm{mM})$ in the pipette. Under these conditions, CPE induced minor pacemaker potential depolarization. (B) The degree of membrane depolarization following exposure to CPE in the presence of GDP- $\beta$-S. Data are presented as the mean \pm standard error of 6 experiments ${ }^{* * *} \mathrm{P}<0.01$ vs. CPE-only treated CTRL samples. GDP- $\beta$-S, guanosine 5 '-( $\beta$-thio) diphosphate trilithium salt; CPE, Citrus unshiu peel extracts, ICCs, interstitial cells of Cajal; CTRL, control.

$3.2 \pm 0.5 \mathrm{mV}$, and the membrane depolarization signal generated by exposure to CPE in the presence of U-73122 was significantly lower compared with CPE-only treated controls $(\mathrm{P}<0.0001)$. By contrast, pretreatment of ICCs with an inactive analog of U-73122 (U-73343; $5 \mu \mathrm{M}$ ) did not significantly alter the pacemaker potential, thus, CPE-induced membrane depolarization was not suppressed by U-73343 (n=5; Fig. 5B). These results suggest that the PLC pathway may be involved in CPE-induced pacemaker depolarization in ICCs.

Involvement of mitogen-activated protein kinases (MAPKs) on CPE-induced ICC pacemaker potential depolarization. Stimulation of muscarinic receptors has been demonstrated to activate MAPKs in a variety of cellular systems (35). Therefore, the role of MAPKs in the effects of CPE on membrane depolarization in cultured ICCs was investigated using a p42/44 MAPK inhibitor, PD98059, a p38 MAPK inhibitor, SB203580, and a c-jun NH2-terminal kinase (JNK) II inhibitor, SP600125. In the presence of PD98059 (10 $\mu \mathrm{M})$, CPE generated partial membrane depolarization signal (n=5; Fig. 6A), which indicates that p42/44 may affect CPE-induced membrane depolarization. In addition, exposure to SB203580 (Fig. 6B) or SP600125 (Fig. 6C) partially inhibited the pacemaker potential depolarization induced by CPE $(n=5)$. Depolarization was significantly reduced in the presence of the MAPK inhibitors compared with CPE treatment alone ( $\mathrm{P}<0.0001$, PD98059; $\mathrm{P}<0.0001, \mathrm{SB} 203580$; $\mathrm{P}<0.0001$, SP600125). Membrane depolarization was inhibited to the greatest degree upon exposure to PD98059, SB203580 and SP600125 (n=5; Fig. 6D and E). These results suggest that
MAPKs are important in modulating CPE-induced ICC pacemaker potential depolarization.

\section{Discussion}

Citrus fruits contain sugar, organic acids and a number of physiologically functional components, including citric acid, ascorbic acid, minerals, coumarins and flavonoids (naringin, hesperidin, neohesperidin, rutin, naringenin, hesperetin, nairutin, and tangeretin) (36,37). C. unshiu is commonly known as the tangerine or mandarin orange. Traditionally, the $C$. unshiu peel has been used as a folk remedy to treat the common cold, dyspepsia, coughs and phlegm production (38). C. unshiu peel contains an abundance of flavonoids, which are known to possess a number of different beneficial effects (39-41). Hesperidin, naringin, and nobiletin $(42,43)$ levels are high in citrus fruits (including $C$. unshiu peel), and are used as chemical quality control markers for $C$. unshiu peel products. Hesperidin is the most abundant flavonoid in citrus peel $(42,43)$. In Korea, extracts of dried C. unshiu peel are sold as commercially available medicines for the treatment of a variety of GI disorders, and single extract doses of $0.5-15 \mathrm{~g}$ are generally recommended (21). However, despite the abundance of these biomolecules in citrus fruits, to the best of our knowledge, there is currently no data regarding the prokinetic activity of CPE. In addition, the molecular and physiological mechanisms underlying the therapeutic effects of $C$. unshiu peel on GI disorders has not yet been elucidated.

ICCs are known to be the pacemaker cells that modulate GI motility by generating pacemaker currents that produce 
A

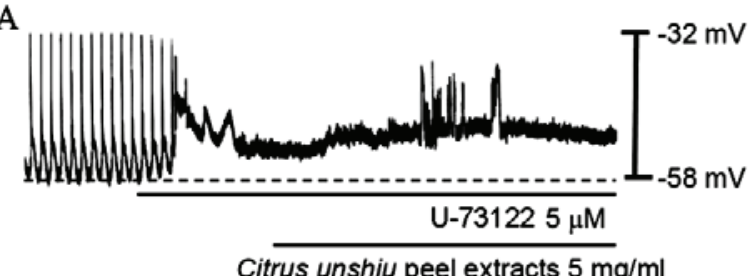

B

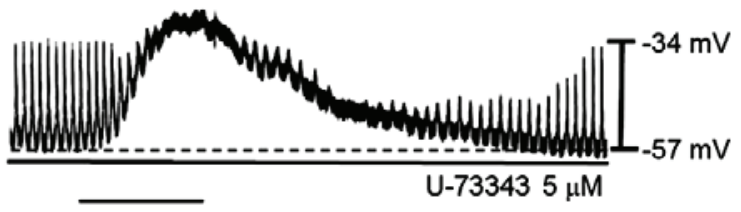

Citrus unshiu peel extracts $5 \mathrm{mg} / \mathrm{ml}$

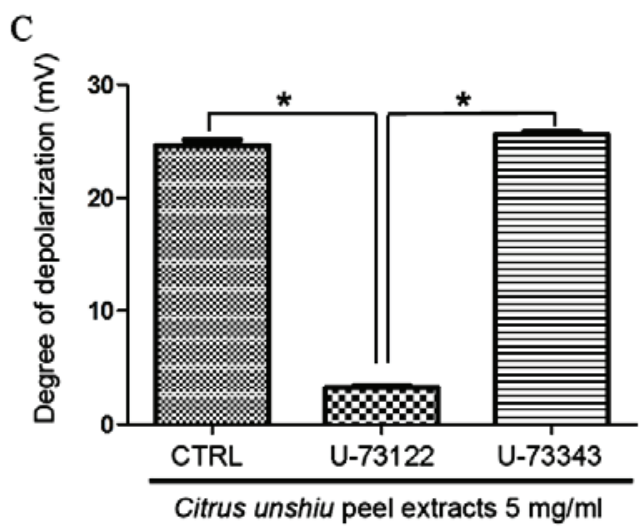

Figure 5. Effect of PLC inhibition on CPE-induced pacemaker potential depolarization in cultured ICCs. Pacemaker potentials of ICCs exposed to CPE $(5 \mathrm{mg} / \mathrm{ml})$ following treatment with (A) U-73122 $(5 \mu \mathrm{M}$; an active PLC inhibitor), which abolished the generation of pacemaker potentials, or (B) U-73343 $(5 \mu \mathrm{M}$; an inactive U-73122 analog), which demonstrated no significant effect on pacemaker potentials and failed to inhibit CPE-induced membrane depolarization. (C) Summary of the degree of membrane depolarization following exposure to CPE in combination with U-73122 or U-73343. Data are presented as the mean \pm standard error of 5 experiments. ${ }^{*} \mathrm{P}<0.05$ vs. the U-73122-treated cells. PLC, phospholipase C; CPE, Citrus unshiu peel extracts, ICCs, interstitial cells of Cajal; CTRL, control.

A

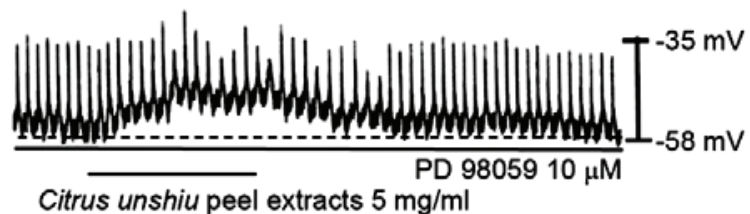

$\mathrm{C}$

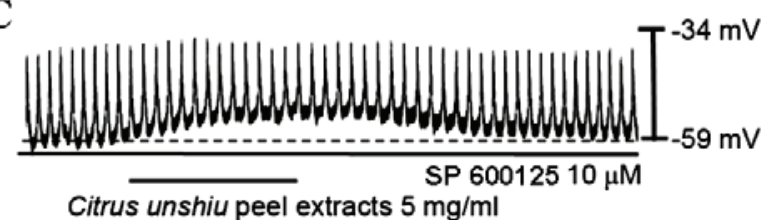

B

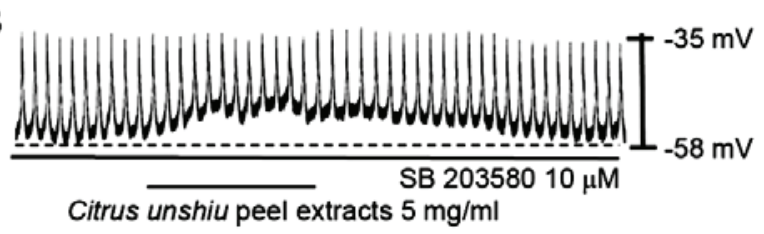

D

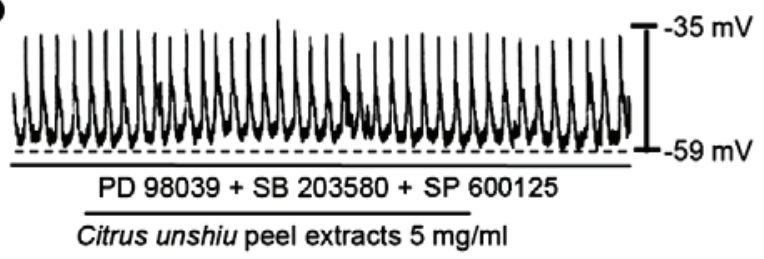

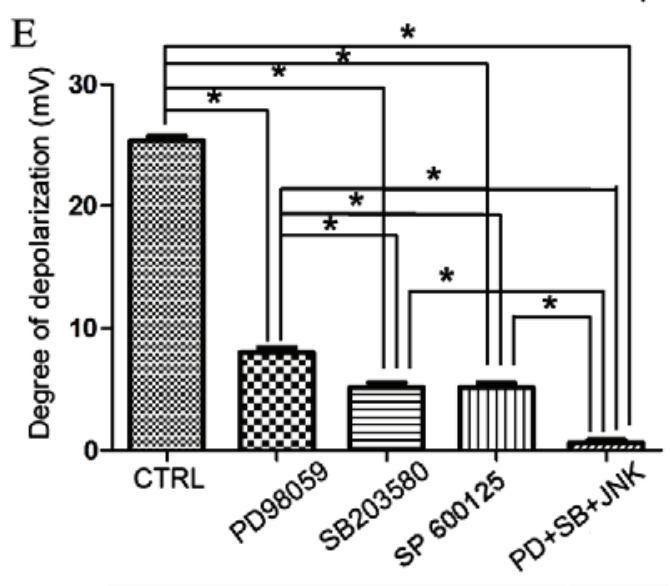

Citrus unshiu peel extracts $5 \mathrm{mg} / \mathrm{ml}$

Figure 6. Effect of MAPK inhibitors on CPE-induced pacemaker potential depolarization in cultured ICCs. Pacemaker potentials of cultured ICCs exposed to CPE (5 mg/ml) in combination with (A) PD98059 (10 $\mu \mathrm{M}$; a p42/44 MAPK inhibitor), (B) SB203580 (10 $\mu \mathrm{M}$; a p38 MAPK inhibitor), (C) SP600125 (10 $\mu$ M; a c-jun NH2-terminal kinase II inhibitor) or (D) PD98059, SB203580 plus SP600125. (E) Summary of the degree of membrane depolarization following exposure to CPE and the MAPK inhibitors. Data are presented as the mean \pm standard error of 5 experiments. "P<0.05 vs. indicated treatment groups. MAPK, mitogen-activated protein kinase; CPE, Citrus unshiu peel extracts, ICCs, interstitial cells of Cajal; CTRL, control. 
slow wave potentials. ICCs are connected to each other and to neighboring smooth muscle cells via gap junctions $(23,24)$. Numerous neurotransmitters, including acetylcholine and 5-hydroxytryptamine, and diverse drugs or traditional herbal medicines (e.g. Ge-Gen-Tang) have been demonstrated to elicit excitatory or inhibitory effects on the pacemaker activity of ICCs $(44,45)$, which supports the notion that ICCs are a critical in the control of smooth muscle motility in the GI tract.

In the present study, CPE was observed to modulate the pacemaker potential of ICCs. CPE produced pacemaker depolarization in current clamp mode. In addition, exposure of ICCs to the $\mathrm{M}_{3}$ muscarinic receptor antagonist, 4-DAMP, inhibited CPE-induced pacemaker depolarization, whereas exposure to the $\mathrm{M}_{2}$ receptor antagonist, methoctramine, did not. When GDP- $\beta-S$ was present in the pipette solution, $\mathrm{CPE}$ induced minor pacemaker depolarization. In addition, membrane depolarization by CPE was inhibited following treatment of ICCs with the active PLC inhibitor U-73122. Furthermore, in the presence of MAPK inhibitors PD98059, SB203580 and SP600125, CPE produced slight membrane depolarization. These results suggest that CPE affects GI motility by modulating ICC pacemaker activity through $\mathrm{G}$ protein-dependent PLC and MAPK pathway-mediated activation of muscarinic $\mathrm{M}_{3}$ receptors.

In the GI tract, $\mathrm{M}_{2}$ and $\mathrm{M}_{3}$ muscarinic receptors are involved in GI motility (46). However, no effect on CPE-induced pacemaker membrane depolarization was observed following exposure of ICCs to methoctramine in the present study. The GI tract is composed of smooth muscle, the enteric nervous system and ICCs. Therefore, we hypothesize that CPE may function to activate the $M_{3}$ receptor in ICCs, and the $M_{2}$ receptor may be involved in modulating smooth muscle or enteric nervous system functions. In support of this notion, So et al (47) suggested that the modulation of pacemaker currents by the muscarinic agonist carbachol is mediated by only muscarinic $\mathrm{M}_{3}$ receptors and not $\mathrm{M}_{2}$ receptors in ICCs. In addition, during the recording of intracellular $\mathrm{Ca}^{2+}$ concentrations using fluo-3-AM dye, carbachol increased intracellular $\mathrm{Ca}^{2+}$ concentrations and $\mathrm{Ca}^{2+}$ oscillations. Therefore, it is possible that CPE may modulate ICC pacemaker potentials through muscarinic $\mathrm{M}_{3}$ receptors only, through an intracellular $\mathrm{Ca}^{2+}$ release-dependent mechanism. Future studies will aim to investigate the effects of CPE in $\mathrm{Ca}^{2+}$ regulation. Acetylcholine muscarinic receptors are a family of $\mathrm{G}$ protein-couples receptors, and are composed of five subtypes $\left(\mathrm{M}_{1}-\mathrm{M}_{5}\right)$. Of these, three $\left(\mathrm{M}_{1}, \mathrm{M}_{3}\right.$, and $\left.\mathrm{M}_{5}\right)$ are coupled with PLC through a $G_{q}$ protein, whereas the $M_{2}$ and $M_{4}$ subtypes inhibit adenylate cyclase through $G_{i}$ or $\mathrm{G}_{\mathrm{o}}$ proteins (35). Stimulation of muscarinic receptors in a variety of cellular systems has been demonstrated to activate MAPKs (35), which are a family of protein kinases that with central roles in signal transduction (48). MAPKs regulate a variety of cellular responses, including inflammation, cell cycle progression, proliferation, differentiation and protein synthesis (49). However, the mechanisms underlying MAPK activation in response to muscarinic receptor stimulation remain to be elucidated. $M_{2}$ and/or $M_{3}$ receptors have been shown to mediate activation of the MAPK pathway $(50,51)$ and muscarinic receptors and the MAPK signaling pathway are known to mediate proliferative responses in various cell types (52-61). Matthiesen et al (52) suggested that these proliferative effects are due to $M_{2}$ receptor and $G_{i}$ protein-mediated MAPK activation, however, several $G$ protein-coupled-MAPK activation pathways have been identified $(53,54)$. Acetylcholine stimulates the proliferation of colon carcinoma cell lines through $\mathrm{M}_{3}$ receptor-dependent phosphorylation of MAPK (55-57). In addition, cholinergic neurotransmitters stimulate the growth of astrocytoma and breast cancer cells through the AKT serine/threonine kinase or MAPK signaling pathways $(58,59)$. Furthermore, acetylcholine stimulates ovarian or lung cancer growth through muscarinic receptor-mediated phosphorylation of MAPK $(60,61)$. In a previous study, the effect of C. unshiu peel on the production of proinflammatory mediators in lipopolysaccharide (LPS)-stimulated RAW264.7 macrophage cells was investigated (16). The results demonstrated that $C$. unshiu peel significantly reduced the phosphorylation of all LPS-stimulated MAPKs in a dose-dependent manner (16). Therefore, we hypothesize that MAPKs are important for the effect of $C$. unshiu peel on ICC membrane depolarization.

In conclusion, the results of the present study suggest that $C$. unshiu peel may be a suitable candidate for the development of prokinetic agents that prevent or alleviate GI disorders.

\section{Acknowledgements}

The present study was supported by the Korean National Research Foundation (grant no. 2014R1A5A2009936), which is funded by the Ministry of Science, ICT and Future Planning (Korean Government).

\section{References}

1. Bai D: Traditional Chinese medicines and new drug development. Pure Appl Chem 65: 1103-1112, 1993.

2. Lim DW, Lee Y and Kim YT: Preventive effects of Citrus unshiu peel extracts on bone and lipid metabolism in OVX rats. Molecules 19: 783-794, 2014.

3. Choi IY, Kim SJ, Jeong HJ, Park SH, Song YS, Lee JH, Kang TH, Park JH, Hwang GS, Lee EJ, et al: Hesperidin inhibits expression of hypoxia inducible factor-1 alpha and inflammatory cytokine production from mast cells. Mol Cell Biochem 305: 153-161, 2007.

4. Yang G, Lee J, Jung ED, Ham I and Choi HY: Lipid lowering activity of Citri unshii pericarpium in hyperlipemic rats. Immunopharmacol Immunotoxicol 30: 783-791, 2008.

5. Braddock RJ: Byproducts of citrus fruits. Food Technol 49: 74-77, 1995.

6. Giannuzzo AN, Boggetti HJ, Nazareno MA and Mishima HT: Supercritical fluid extraction of naringin from the peel of Citrus paradisi. Phytochem Anal 14: 221-223, 2003.

7. Jeong SM, Kim SY, Kim DR, Jo SC, Nam KC, Ahn DU and Lee SC: Effect of heat treatment on the antioxidant activity of extracts from citrus peels. J Agric Food Chem 52: 3389-3393, 2004.

8. Kim DK, Lee KT, Eun JS, Zee OP, Lim JP, Eum SS, Kim SH and Shin TY: Anti-allergic components from the peels of Citrus unshiu. Arch Pharm Res 22: 642-645, 1999.

9. Park SH, Park EK and Kim DH: Passive cutaneous anaphylaxis-inhibitory activity of flavanones from Citrus unshiu and Poncirus trifoliata. Planta Med 71: 24-27, 2005.

10. Jo CR, Park BJ, Chung SH, Kim CB, Cha BS and Byun MW: Antibacterial and anti-fungal activity of citrus (Citrus unshiu) essential oil extracted from peel by-products. Food Sci Biotechnol 13: 384-386, 2004

11. Min KY, Kim HJ, Lee KA, Kim KT and Paik HD: Antimicrobial activity of acid-hydrolyzed Citrus unshiu peel extract in milk. J Dairy Sci 97: 1955-1960, 2014. 
12. Lee S, Ra J, Song JY, Gwak C, Kwon HJ, Yim SV, Hong SP, Kim J,Lee KH, Cho JJ, et al: Extracts from Citrus unshiu promote immune mediated inhibition of tumor growth in a murine renal cell carcinoma model. J Ethnopharmacol 133: 973-979, 2011

13. Park HJ, Jung UJ, Cho SJ, Jung HK, Shim S and Choi MS: Citrus unshiu peel extract ameliorates hyperglycemia and hepatic steatosis by altering inflammation and hepatic glucoseand lipid-regulating enzymes in $\mathrm{db} / \mathrm{db}$ mice. J Nutr Biochem 24 419-427, 2013

14. Lee YH, Kim YS, Song M, Lee M, Park J and Kim H: A herbal formula HT048, Citrus unshiu and Crataegus pinnatifida, prevents obesity by inhibiting adipogenesis and lipogenesis in 3T3-L1 preadipocytes and HFD-induced obese rats. Molecules 20: 9656-9670, 2015.

15. Kim KS, Rhee HI, Park EK, Jung K, Jeon HJ, Kim JH, Yoo H, Han CK, Cho YB, Ryu CJ, et al: Anti-inflammatory effects of Radix Gentianae Macrophyllae (Qinjiao), Rhizoma Coptidis (Huanglian) and Citri Unshiu Pericarpium (Wenzhou migan) in animal models. Chin Med 3: 10, 2008

16. Oh YC, Cho WK, Jeong YH, Im GY, Yang MC, Hwang YH and Ma JY: Anti-inflammatory effect of Citrus unshiu peel in LPS-stimulated RAW 264.7 macrophage cells. Am J Chin Med 40: 611-629, 2012.

17. Bocco A, Cuvelier ME, Richard $\mathrm{H}$ and Berset C: Antioxidant activity and phenolic composition of citrus peel and seed extracts. J Agri Food Chem 46: 2123-2129, 1998.

18. Jeong SM, Kim SY, Kim DR, Jo SC, Nam KC, Ahn DU and Lee SC: Effect of heat treatment on the antioxidant activity of extracts from Citrus peels. J Agri Food Chem 52: 3389-3393, 2004.

19. Yang X, Kang SM, Jeon BT, Kim YD, Ha JH, Kim YT and Jeon YJ: Isolation and identification of an antioxidant flavonoid compound from citrus-processing byproduct. J Sci Food Agric 91: 1925-1927, 2011.

20. Suzuki M, Sasaki K, Yoshizaki F, Oguchi K, Fujisawa M and Cyong JC: Anti-hepatitis C virus effect of Citrus unshiu peel and its active ingredient nobiletin. Am J Chin Med 33: 87-94, 2005.

21. Kim CM, Shin MK, Ahn DG and Lee KS: Chungyak Daesajun. Jungdam, Seoul 8: 4026-4030, 1997

22. Lyu JH and Lee HT: Effects of dried Citrus unshiu peels on gastrointestinal motility in rodents. Arch Pharm Res 36: 641-648, 2013.

23. Ward SM, Burns AJ, Torihashi S and Sanders KM: Mutation of the proto-oncogene c-kit blocks development of interstitial cells and electrical rhythmicity in murine intestine. J Physiol 480 : 91-97, 1994.

24. Huizinga JD, Thuneberg L, Klüppel M, Malysz J, Mikkelsen HB and Bernstein A: W/kit gene required for interstitial cells of Cajal and for intestinal pacemaker activity. Nature 373: 347-349, 1995

25. Kim BJ, Kwon YK, Kim E and So I: Effects of histamine on cultured interstitial cells of cajal in murine small intestine. Korean J Physiol Pharmacol 17: 149-156, 2013.

26. Kim BJ, Lim HH, Yang DK, Jun JY, Chang IY, Park CS, So I, Stanfield PR and Kim KW: Melastatin-type transient receptor potential channel 7 is required for intestinal pacemaking activity. Gastroenterology 129: 1504-1517, 2005.

27. Ahn DK: Illustrated guide to clinical medical herbs. Hyeonamsa Publ. Corp., Seoul, pp147-148, 2012.

28. Goto K, Matsuoka S and Noma A: Two types of spontaneous depolarizations in the interstitial cells freshly prepared from the murine small intestine. J Physiol 559: 411-422, 2004.

29. Huizinga JD, Chang G, Diamant NE and El-Sharkawy TY: Electrophysiological basis of excitation of canine colonic circular muscle by cholinergic agents and substance P. J Pharmacol Exp Ther 231: 692-699, 1984

30. Inoue R and Chen S: Physiology of muscarinic receptor operated nonselective cation channels in guinea-pig ileal smooth muscle. EXS 66: 261-268, 1993

31. Epperson A, Hatton WJ, Callaghan B, Doherty P, Walker RL, Sanders KM, Ward SM and Horowitz B: Molecular markers expressed in cultured and freshly isolated interstitial cells of Cajal. Am J Physiol Cell Physiol 279: C529-C539, 2000.

32. Komori S, Kawai M, Takewaki T and Ohashi H: GTP-binding protein involvement in membrane currents evoked by carbachol and histamine in guinea-pig ileal muscle. J Physiol 450: 105-126, 1992.

33. Ogata $\mathrm{R}$, Inoue $\mathrm{Y}$, Nakano $\mathrm{H}$, Ito $\mathrm{Y}$ and Kitamura $\mathrm{K}$ : Oestradiol-induced relaxation of rabbit basilar artery by inhibition of voltage-dependent Ca channels through GTP-binding protein. Br J Pharmacol 117: 351-359, 1996.
34. Sakamoto T, Unno T, Matsuyama H, Uchiyama M, Hattori M, Nishimura $M$ and Komori S: Characterization of muscarinic receptor-mediated cationic currents in longitudinal smooth muscle cells of mouse small intestine. J Pharmacol Sci 100: 215-226, 2006.

35. Slack BE: The M3 muscarinic acetylcholine receptor is coupled to mitogen-activated protein kinase via protein kinase $C$ and epidermal growth factor receptor kinase. Biochem J 348: 381-387, 2000

36. Tanizawa H, Ohkawa Y, Takino Y,Miyase T, Ueno A, Kageyama T and Hara S: Studies on natural antioxidants in citrus species. I. Determination of antioxidative activities of citrus fruits. Chem Pharm Bull (Tokyo) 40: 1940-1942, 1992.

37. Kawaii S, Tomono Y, Katase E, Ogawa K and Yano M: Quantitation of flavonoid constituents in citrus fruits. J Agric Food Chem 47: 3565-3571, 1999.

38. Kimura T, But PPH, Guo JX and Sung CK: International collation of traditional and folk medicine: Northeast Asia. River Edge: World Scientific Publishing Co., 1996.

39. Jung UJ, Lee MK, Park YB, Kang MA and Choi MS: Effect of citrus flavonoids on lipid metabolism and glucose-regulating enzyme mRNA levels in type-2 diabetic mice. Int J Biochem Cell Biol 38: 1134-1145, 2006

40. Abeysinghe DC, Li X, Sun C, Zhang W, Zhou C and Chen K: Bioactive compounds and antioxidant capacities in different edible tissues of citrus fruit of four species. Food Chem 104: 1338-1344, 2007

41. Funaguchi N, Ohno Y, La BL, Asai T, Yuhgetsu H, Sawada M, Takemura G, Minatoguchi S, Fujiwara T and Fujiwara H: Narirutin inhibits airway inflammation in an allergic mouse model. Clin Exp Pharmacol Physiol 34: 766-770, 2007.

42. Lu Y, Zhang C, Bucheli P and Wei D: Citrus flavonoids in fruit and traditional Chinese medicinal food ingredients in China. Plant Food Hum Nutr 61: 57-65, 2006

43. Ma YQ, Ye XQ, Fang ZX, Chen JC, Xu GH and Liu DH: Phenolic compounds and antioxidant activity of extracts from ultrasonic treatment of Satsuma Mandarin (Citrus unshiu Marc.) peels. J Agri Food Chem 56: 5682-5690, 2008.

44. Wu MJ, Kee KH, Na J, Kim SW, Bae Y, Shin DH, Choi S, Jun JY, Jeong HS and Park JS: Pituitary adenylate cyclase-activating polypeptide inhibits pacemaker activity of colonic interstitial cells of cajal. Korean J Physiol Pharmacol 19: 435-440, 2015.

45. Lee S, Gim H, Shim JH, Jung Kim H, Lee JR, Kim SC, Kwon YK, Ha KT, So I and Kim BJ: The traditional herbal medicine, Ge-Gen-Tang, inhibits pacemaker potentials by nitric oxide/cGMP dependent ATP-sensitive $\mathrm{K}(+)$ channels in cultured interstitial cells of Cajal from mouse small intestine. J Ethnopharmacol 170: 201-209, 2015.

46. Ehlert FJ, Pak KJ and Griffin MT: Muscarinic agonists and antagonists: Effects on gastrointestinal function. Handb Exp Pharmacol 208: 343-374, 2012.

47. So KY, Kim SH, Sohn HM, Choi SJ, Parajuli SP, Choi S, Yeum CH, Yoon PJ and Jun JY: Carbachol regulates pacemaker activities in cultured interstitial cells of Cajal from the mouse small intestine. Mol Cells 27: 525-531, 2009.

48. Garrington TP and Johnson GL: Organization and regulation of mitogen-activated protein kinase signaling pathways. Curr Opin Cell Biol 11: 211-218, 1999.

49. Lukacs NW, Strieter RM, Chensue SW, Widmer M and Kunkel SL: TNF-alpha mediates recruitment of neutrophils and eosinophils during airway inflammation. J Immunol 154: 5411-5417, 1995.

50. Cook AK, Carty M, Singer CA, Yamboliev IA and Gerthoffer WT: Coupling of $\mathrm{M}(2)$ muscarinic receptors to ERK MAP kinases and caldesmon phosphorylation in colonic smooth muscle. Am J Physiol Gastrointest Liver Physiol 278: G429-G437, 2000.

51. Budd DC, Willars GB, McDonald JE and Tobin AB: Phosphorylation of the Gq/11-coupled M3-muscarinic receptor is involved in receptor activation of the ERK-1/2 mitogen-activated protein kinase pathway. J Biol Chem 276: 4581-4587, 2001.

52. Matthiesen S, Bahulayan A, Kempkens S, Haag S, Fuhrmann R, Stichnote C, Juergens UR and Racké K: Muscarinic receptors mediate stimulation of human lung fibroblast. Am J Respir Cell Mol Biol 35: 621-627, 2006.

53. Luttrell LM: Activation and targeting of mitogen-activated protein kinases by G-protein-coupled receptors. Can J Physiol Pharmacol 80: 375-382, 2002.

54. Gu J and Iyer VR: PI3K signaling and mRNA expression during the response of quiescent human fibroblasts to distinct proliferative stimuli. Genome Biol 7: R42, 2006. 
55. Frucht H, Jensen RT, Dexter D, Yang WL and Xiao Y: Human colon cancer cell proliferation mediated by the M3 muscarinic cholinergic receptor. Clin Cancer Res 5: 2532-2539, 1999.

56. Cheng K, Zimniak P and Raufman JP: Transactivation of the epidermal growth factor receptor mediates cholinergic agonist-induced proliferation of H508 human colon cancer cells. Cancer Res 63: 6744-6750, 2003.

57. Ukegawa JI, Takeuchi Y, Kusayanagi S and Mitamura K: Growth-promoting effect of muscarinic acetylcholine receptors in colon cancer cells. J Cancer Res Clin Oncol 129: 272-278, 2003

58. Guizzetti M and Costa LG: Activation of phosphatidylinositol 3 kinase by muscarinic receptors in astrocytoma cells. Neuroreport 12: 1639-1642, 2001.
59. Jimenez E and Montiel M: Activation of MAP kinase by muscarinic cholinergic receptors induces cell proliferation and protein synthesis in human breast cancer cells. J Cell Physiol 204: 678-686, 2005.

60. Oppitz M, Möbus V, Brock S and Drews U: Muscarinic receptors in cell lines from ovarian carcinoma: Negative correlation with survival of patients. Gynecol Oncol 85: 159-164, 2002

61. Song P, Sekhon HS, Lu A, Arredondo J, Sauer D, Gravett C, Mark GP, Grando SA and Spindel ER: M3 muscarinic receptor antagonists inhibit small cell lung carcinoma growth and mitogen-activated protein kinase phosphorylation induced by acetylcholine secretion. Cancer Res 67: 3936-3944, 2007. 